KAMILLA BISKUPSKA

ORCID: 0000-0002-6120-3405

Uniwersytet Opolski

Wydział Nauk Społecznych

\title{
Breslau. Nazwa miasta jako dziedzictwo kulturowe zarys problematyki w perspektywie analizy dyskursu historycznego
}

\begin{abstract}
Abstrakt
W artykule śledzę taktyki przywoływania (i unikania) wcześniejszych nazw współczesnego Wrocławia jako elementu tworzenia jego dziedzictwa kulturowego. Na przykładzie opracowań historycznych i wykorzystując metodę analizy dyskursu, pokazuję mechanizmy kreowania różnie akcentowanych przeszłości miasta. Opierając się na użyciu nazwy historycznej (na przykład Breslau) czy konsekwentnie tylko współczesnej (Wrocław), wskazuję, że za strategią wyboru nazwy stoją odmienne, ideologicznie uwarunkowane, narracje. Jedni badacze, używając wcześniejszych, historycznych nazw miasta, tworzą obraz ciągle zmieniającego się europejskiego ośrodka miejskiego, natomiast drudzy, posługując się wyłącznie współczesną nazwą, konstruują obraz miasta jako kontynuatora wielowiekowej miejskiej tradycji, z dominacją polskiej perspektywy narracji historycznej.
\end{abstract}

Słowa kluczowe: dziedzictwo kulturowe, Wrocław, Breslau, pamięć społeczna, analiza dyskursu.

\section{Wprowadzenie}

Przedmiotem analiz i refleksji jest Wrocław - miasto o trudnych, złożonych losach, które od kilku dekad — od rozpoczętego w 1989 roku procesu przemian — układa się na nowo ze swoją wielowiekową historią. Spoglądam na Wrocław przez pryzmat proponowanych w dyskursie dominującym obrazów przeszłości, wpierających owo (re)formowanie tożsamości miasta. Najważniejszym punktem odniesienia moich refleksji jest pojęcie „dziedzictwo”. Termin ten najkrócej można zdefiniować jako „wytwory człowieka i natury, które mają szczególną wartość kulturową bądź naukową dla rozwoju cywilizacji” (Galusek, Jagodzińska 2014: 111), przy czym wytwory 
ludzi określa się mianem dziedzictwa kulturowego. Nie jest ono jednakże synonimem zabytku - uznanego dobra kultury i (najczęściej) instytucjonalnie objętego opieką państwa. Pojęcie dziedzictwa jest bardziej płynne, uznaniowe - zawiera treści zarówno materialne, jak i niematerialne, a ich wybór podlega społecznym negocjacjom: „dziedzictwem jest wszystko to, co współcześni wybierają z przeszłości, jaką sami wykreowali na użytek czasów obecnych lub w celu przekazania potomnym. Dziedzictwo to proces, a nie typ zasobów" (Ashworth 2007: 32).

Kategoria dziedzictwa kulturowego jest soczewką, przez którą przyglądam się sposobom konstruowania przeszłości Wrocławia we współczesnym dyskursie historycznym. Koncentruję się na pracach naukowych, ponieważ — zgodnie z założeniami analizy dyskursu - uważam, że dyskurs naukowy jest polem walki o znaczenie i podlega kulturowemu negocjowaniu w tej samej mierze co dyskurs potoczny, a przy tym traktowany jest zarówno przez badaczy, jak i przez zwykłych ludzi jako neutralny ( $w$ rozumieniu: pozbawiony emocji, wartościowań, uprzedzeń i stereotypów) i niezmienny (zob. np. Gilbert, Mulkay 1984; Potter, Wetherell 1994; Wooffitt 2005). Badacze dyskursu przyjmują, że opracowania historyczne są uwarunkowane rzeczywistością społeczno-kulturową, w której działa historyk: „konstruowanie historii jest społeczną, refleksyjną praktyką, w której przeszłość jest bez przerwy dekonstruowana i rekonstruowana $\mathrm{z}$ wielu różnych punktów widzenia" (Coffin 2003: 219). Sami historycy przyznają, że społeczne i kulturowe otoczenie wpływa na zakres i treść ich studiów: „historyk ma własne i w swej epoce uformowane przekonania etyczne, społeczne, swoje poczucie sprawiedliwości, swoje rozumienie, co jest prawem, a co zbrodnią, co jest mądrością, a co przesądem, co jest wiernością, a co jest zdradą" (Jedlicki 1993: 160).

Prace historyczne były (i nadal są) ważnym elementem konstruowania tożsamości wrocławian. Narodziny Wrocławia na szczątkach Breslau - miasta dla Polaków obcego kulturowo i obciążonego faszystowskim brzemieniem - były wynikiem politycznego kompromisu i przypadku: „to, że [Wrocław - K.B.] jest dziś miastem polskim, zależało od decyzji kilku polityków, które w tamtych okolicznościach mogły mieć zupełnie inny finał" (Thum 2005: 17). Co więcej, Wrocław, inaczej niż Gdańsk, nie był spełnieniem zarówno przedwojennych, jak i powojennych marzeń polskich władz o odzyskanym polskim mieście — jak podkreślają Norman Davies i Roger Moorhouse: „W XX wieku związki Breslau z tzw. dziedzictwem piastowskim niemal całkowicie ulotniły się już z polskiego imaginarium narodowego" (2011: 448). Z tych względów jeszcze wiele lat po wojnie polskość miasta była dla osiedleńców nieoczywista i pozbawiona głębszego uzasadnienia dziejowego. Dlatego w pierwszych powojennych dekadach opracowania historyczne i płynące z nich narracje na temat przeszłości wypełniały pustkę tożsamościową i poczucie wykorzeniania mieszkańców.

Legitymizacją powojennego porządku były przede wszystkim opowieści fundacyjne - zaakceptowane (i rozwijane) przez mieszkańców narracje o polskości wywodzącej się od średniowiecznego rodu śląskich Piastów, o licznej i wpływowej 
Polonii w Breslau, o powrocie miasta do „polskiej macierzy” czy wreszcie o pierwszych polskich osiedleńcach-pionierach (zob. Thum 2005; Biskupska 2020). Ten, początkowo przydatny wrocławianom (choć bardzo wybiórczy), obraz przeszłości miasta miał znaczące konsekwencje dla formowania tożsamości kolejnych powojennych pokoleń — zarówno badaczy, jak i mieszkańców. Z jednej strony fizyczne ślady po Breslau definiowały miejską przestrzeń - niemiecka była architektura miejska (kamienice, osiedla robotnicze, budynki użyteczności publicznej), układ ulic, zieleń miejska, wyposażenie mieszkań. $Z$ drugiej strony cała ta substancja codziennego życia była niewidzialna (nienazwana) na poziomie dyskursu publicznego - zastąpiona narracjami o odległej („piastowskiej”) przeszłości miasta ${ }^{1}$. Jak podsumował ten czas Andrzej Zawada: „Korzenie polskiej teraźniejszości mocno już siedziały w nadodrzańskim gruncie, ale przyszłość bardziej pociągała od przeszłości. Przeszłość była zbyt cudza, zbyt obca, by budzić zaciekawienie" (2015: 44). Dyskursywna nieobecność spadku po Breslau trwała do politycznego przesilenia 1989 roku, a ściślej mówiąc - do początków XXI wieku, kiedy to badacze zaczęli stawiać pytania o dziedzictwo kulturowe Breslau (zob. np. Dzikowska 2006; Margiela-Korczewska 2011, Biskupska 2018).

\section{Dwa spojrzenia na Wrocław}

$\mathrm{W}$ pracy badawczej interesują mnie nie tyle opracowania na temat postrzegania przeszłości miasta przez mieszkańców (jest to temat prac socjologów i historyków) czy pisarzy (prace literaturoznawców), ile raczej schematy myślenia o Wrocławiu, leżące u podstaw tychże projektów badawczych. Mogą to być na przykład stereotypowe narracyjne obrazy miasta piastowskiego, miasta europejskiego (metropolii europejskiej), miasta (po)niemieckiego. To zagadnienie wielowątkowe, wymagające pogłębionej refleksji i przyszłych badań. W tym miejscu, w celu zarysowania interesującej mnie problematyki, przedstawię jedynie studium przypadku - przywoływanie we współczesnych opracowaniach historycznych przedwojennej nazwy miasta: Breslau.

Nazwa miasta jest ważnym elementem jego tożsamości - jest wizytówką, esencją miejskiego uniwersum:

Vilnius na Litwie to jednocześnie Wilna, Wilno, Vilne. Lemberg to jednocześnie Leopolis, Lwów, Lviv, Tallin to Reval, Oradea to Grosswardein i Navygrad. To nie tylko nominalistyczna gra w ciuciubabkę. Każda $\mathrm{z}$ tych nazw reprezentuje inny segment, inną kulturę, inny język, inną tradycję, a wszystkie razem z niewielkim naddatkiem składają się na miasto, o którym mowa. W ten sposób

1 To poczucie ambiwalencji towarzyszące życiu w powojennym Wrocławiu można naszkicować z pomocą wspomnień wrocławskiej pisarki Ewy Stachniak: „we Wrocławiu nie było historii, poza piastowską gdzieś tam w mroku dziejów. Przeszłość nie istniała [...]. Ta historyczna amnezja sprawiła, że zawsze czułam się we Wrocławiu obco. To miasto wydawało mi się uboższe, niepełne, nie moje" (za: Tuszyńska 2003: 20). 
nazywa się różne życiorysy, różne pochodzenia, różne miejsca zamieszkania i ulice, miasta i „miejsca kultury". (Schlögel 2009: 302)

Zmiana nazwy jest granicznym momentem dla miasta, często związanym z dążeniem do unicestwienia wcześniejszej miejskiej tożsamości: „Nazwy miast mogą się zmieniać. [...]. Przemianowania te zachodzą zazwyczaj w czasie znacznych przemian społeczno-politycznych. Nie są one obojętne dla żywej substancji miasta i jego obrazu” (Żyłko 2000: 14). Analiza sposobów uobecniania w dyskursie historycznych wcześniejszych nazw miasta daje możność przyjrzenia się wspomnianym narracyjnym wzorom leżącym u podstaw prowadzonych badań. Jak zauważa Norman Davies: „W pracach tego rodzaju [opracowaniach historycznych - K.B.] szczególnie istotne jest nazewnictwo. Nazwy nie tylko identyfikują ludzi i miejsca, ale przede wszystkim ujawniają punkty widzenia i przesądy tych, którzy się nimi posługują" (Davies 2011a: 12). Dlatego też strategie przywoływania minionych nazw są niezwykle interesującym fenomenem dla badacza dyskursu zainteresowanego mechanizmami tworzenia pamięci społecznej, w tym kreowania treści dziedzictwa kulturowego.

Zajmuję się przede wszystkim współczesnym funkcjonowaniem nazwy Breslau ${ }^{2}$, ponieważ to na gruzach tego miasta narodził się Wrocław — to ramy architektoniczne i infrastrukturalne dziewiętnasto- i dwudziestowiecznego ośrodka miejskiego tworzyły powojenne miasto i mają wpływ na jego współczesne oblicze. Innymi słowy są one istotnym punktem odniesienia kreowania treści dziedzictwa kulturowego. Sposoby wyrażania obecności (i nieobecności) nazwy Breslau w dyskursie historycznym przedstawię na przykładzie dwóch ważnych prac odtwarzających wrocławską przeszłość. Pierwszą z nich jest wydane w 2002 roku historiograficzne opracowanie dziejów miasta (od około 1000 do 2000 roku) autorstwa Normana Daviesa i Rogera Moorhouse'a, Microcosm: Portrait of a Central European City. Vratislavia, Breslau, Wrocław (pierwsze polskie wydanie ukazało się również w 2002 roku pod tytułem Mikrokosmos. Portret miasta środkowoeuropejskiego. Vratislavia, Breslau, Wrocław) (Davies, Moorhouse 2011). Drugi tytuł to Orbis Wratislaviae. Wrocław $w$ relacjach dawnych $i$ współczesnych - antologia zredagowana przez Krzysztofa Ruchniewicza i Marka Zyburę (2018). Publikacja ta jest zbiorem fragmentów relacji z podróży, listów, pamiętników i wspomnień o mieście, spisywanych od XV wieku do czasów współczesnych.

Obie prace opowiadają o niezwykle złożonej, dalszej i bliższej, przeszłości miasta w sposób barwny i przyjazny dla zwykłego czytelnika (zwykłego w znaczeniu niehistoryka). Są to książki wspierające wizerunek współczesnego Wrocławia jako spadkobiercy ośrodka miejskiego o wielowiekowej, wielokulturowej tradycji, znaczącego punktu na mapie Europy ${ }^{3}$. Mają one być także postrzegane jako prace wy-

2 Wrocław w przeszłości nosił wiele imion. Nowożytne nazwy miasta według Normana Daviesa i Rogera Moorhouse'a (2011) to: Wrotizla (1000-1335), Wretslaw (1335-1526), Presslaw (1526-1741), Bresslau (1741-1871), Breslau (1871-1945) i Wrocław (od 1945 roku).

3 Taki obraz miasta jest od wielu lat propagowany przez władze Wrocławia. Samorząd miejski wspierał także wydanie obu książek. Norman Davies w Przedmowie (Davies 2011b) opisuje spotka- 
chodzące poza polską perspektywę historyczną i budujące podstawę społecznego polsko-niemieckiego dialogu ${ }^{4}$. Podsumowując, należy wskazać, że pozycje te są istotnymi aktorami w kształtowaniu dziedzictwa kulturowego miasta. Praktyki definiowania owego dziedzictwa przebiegają jednak inaczej we wskazanych książkach - różnią się one na przykład podejściem do historycznych nazw miasta.

\section{Przypadek pierwszy: Mikrokosmos. Portret miasta środkowoeuropejskiego}

Temat nazewnictwa jest w książce Daviesa i Moorhouse’a niezwykle istotny — Norman Davies już we wstępie do publikacji poświęca wiele miejsca wyjaśnieniu przyjętej w dziele strategii używania historycznych nazw miasta. Zaznacza on między innymi:

Niniejsza książka nie mogła nosić tytułu Dzieje Wrocławia dokładnie z tych samych powodów, dla których wersja niemiecka nie mogła się nazywać Die Geschichte Breslaus [...]. Uważaliśmy, że byłoby niewłaściwe, gdyby miasto, które wielokrotnie zmieniało swoje afiliacje polityczne i kulturowe, miało wystąpić pod jakimś jednym szyldem narodowym. (Davies 2011b: 9)

Dlatego też historyczne nazwy miasta są przywoływane zgodnie z przedstawianą epoką historyczną (choć także z polską fleksją). Oto przykładowe charakterystyki miasta: „W XIV wieku ustrój Wretslawia stopniowo ewoluował” (Davies, Moorhouse 2011: 168) i „Pod panowaniem Habsburgów przewaga ludności niemieckiej w Presslawiu stała się jeszcze bardziej wyraźna" (Davies, Moorhouse 2011: 208). Natomiast miasto z przełomu lat dwudziestych i trzydziestych XX wieku opisywane jest następująco:

nie z ówczesnym prezydentem miasta Bogdanem Zdrojewskim, który „mówił o kłopotach Wrocławia z własną przeszłością i tożsamością. [...] stwierdził następnie, że nowa historia miasta byłaby nader pomocna w pogłębianiu obecnego klimatu porozumienia i dodał — nieco zaskakująco — że nie mógłby jej napisać »ani Niemiec, ani Polak«. Zakończył sugestią, że to ja powinienem być jej autorem” (Davies 2011b: 11). Natomiast tom Orbis Wratislaviae otwiera przedmowa kolejnego prezydenta miasta Rafała Dutkiewicza, który zachęcając do lektury, sięga po cliché często wykorzystywany w opowieści o Wrocławiu (Wrocław - miasto otwarte, miasto spotkań): „Dopiero spojrzenie na wielowiekową historię miasta pokazuje jego wielkie bogactwo i ogromny potencjał. Miasto spotkań, miasto tolerancji, krótko mówiąc - miasto otwarte" (Dutkiewicz 2018: 6). Warto na marginesie wspomnieć, że w wypowiedzi prezydenta miasta pojawia się także wątek piastowskiej opowieści fundacyjnej: „przygotowaliśmy na placu Biskupa Nankiera ścieżkę edukacyjną, która w pigułce ukazuje najważniejsze wydarzenia w dziejach miasta. Nierzadko można spotkać tu grupy z przewodnikami, którzy podczas spaceru opowiadają gościom o naszej historii, rozpoczynając od średniowiecza. To dobry wstęp do dalszego poznawania miasta" (Dutkiewicz 2018: 6).

4 Są to opracowania powstałe przy wsparciu finansowym niemieckich partnerów. Publikację Daviesa i Moorhouse'a wspierały finansowo między innymi Fundacja Roberta Boscha oraz Fundacja Alfried Krupp von Bohlen und Halbach. Z kolei opracowanie Ruchniewicza i Zybury zostało wsparte przez Niemieckie Towarzystwo Kulturalno-Społeczne we Wrocławiu. 
1 kwietnia 1928 roku obszar Breslau wzrósł ponad trzykrotnie [...]. Intensywne prace budowlane objęły wówczas dzielnice: Pöpelwitz (Popowice), Westend, Gräbschen (Grabiszyn) i Zimpel (Sępolno) [...]. Zimpel [...] w 1939 roku liczył około 11 tysięcy mieszkańców. Jego ulicom nadano „ptasie” nazwy: Amselweg, Drosselweg, Falkenweg, Sperlingsweg i Elsterweg (Kosia, Droździa, Sokola, Wróbla i Srocza). (Davies, Moorhouse 2011: 409)

W poznawaniu dziejów Breslau towarzyszą nam nie tylko niemieckie nazwy miejsc, ale i fragmenty zapisanych w języku niemieckim dokumentów epoki (relacji, wierszy, listów) z dołączonym tłumaczeniem na język polski. Poza wartością faktograficzną takie zanurzenie się w języku ówczesnej kultury pozwala pełniej i wiarygodniej odtworzyć ówczesny miejski „mikrokosmos”, a także przedstawić go w postaci bardziej oczywistej, nawet swojskiej dla czytelników.

Mimo że autorzy starają się wiernie odtwarzać kolejne rzeczywistości miejskie — nie tylko stolicy Dolnego Śląska, ale całej ziemi śląskiej — to ten zamysł nie w pełni jednak się udaje. Przykładowo, pisząc o miastach i miejscowościach z czasów austriackich i niemieckich autorzy, zgodnie z przyjętymi założeniami, powinni je przedstawiać w niemieckiej postaci (z polskim tłumaczeniem w nawiasie): „Pokój westfalski zezwolił także na wznoszenie protestanckich Friedenskirchen, czyli drewnianych »kościołów pokoju«; zbudowano je za murami Schweidnitz (Świdnica), Jauer (Jawor) i Glogau (Głogów)" (Davies, Moorhouse 2011: 195). Często jednak te same nazwy są prezentowane po polsku (z niemieckim tłumaczeniem), a czasem tylko po polsku (sic!); oto przykład: „Dzięki książęcemu patronatowi zakon rozszerzył swoją działalność na Kluczbork (Kreuzburg), Bolesławiec (Bunzlau), Ziębice, Świdnicę (Schweidnitz) i Legnicę” (Davies, Moorhouse 2011: 104). Ta polska „Legnica” już na kolejnych stronach funkcjonuje wyłącznie w niemieckiej formie „Liegnitz”: „Na przykład Striegau (Strzegom), leżące na drodze do Liegnitz, podźwignęło się dopiero po 1713 roku" (Davies, Moorhouse 2011: 225).

Ważnym punktem odniesienia pracy Daviesa i Moorhouse’a jest idea wielokulturowego dziedzictwa miasta, co zresztą podkreślają sami autorzy:

pragniemy przezwyciężyć historiograficzną rywalizację, która doprowadziła do powstania dwóch konkurencyjnych wizji: „niemieckiego miasta Breslau” i „polskiego Wrocławia”. W tym celu podkreślamy znaczenie wątków czeskich, austriackich i żydowskich [...]. (Davies, Moorhouse 2011: 27-28)

Poszukiwanie i opisywanie wątków czeskich czy habsburskich sprzed setek lat nie odpowiada jednak na pytania o współczesne życie wrocławian wśród odziedziczonej materii - głównie niemieckiego dziewiętnasto- i dwudziestowiecznego miasta. Te narracyjne wątki odnoszące się do dalekiej przeszłości są dla współczesnej egzystencji wrocławian równie mityczne i nawet mniej widzialne, co „udowadniające" mit piastowski obecne w przestrzeni miasta gotyckie kościoły. 


\section{Przypadek drugi: Orbis Wratislaviae. Wrocław w relacjach dawnych i współczesnych}

Redaktorzy pracy Orbis Wratislaviae przyjmują inną niż Davies i Moorhouse strategię nazywania miasta. Mimo umieszczonej w tytule łacińskiej nazwy „Wratislavia”5 teksty pochodzące z różnych wieków i spisane przez autorów wywodzących się z odmiennych kontekstów kulturowych (i językowych) są opisami Wrocławia ${ }^{6}$. Wyjątkiem jest termin „Festung Breslau”, o którym piszę osobno w dalszej części artykułu.

W większości przytaczanych opowieści nazwa Wrocław pojawia się w pierwszym zdaniu - niezależnie czy będzie to tekst z XV wieku: „Wrocław w śląskiej położony krainie, jest wspaniałym, tak od Niemców, jak i od Sarmatów bardzo szanowanym miastem” (Schedel 2018: 8); opis z XVI wieku: „Wrocław jest nie tylko stolicą księstwa wrocławskiego [...], ale całego Śląska" (Zeiller 2018: 18); relacja z XIX wieku: „Do Wrocławia przybyliśmy wcześnie rano, lecz, że był to czas jarmarku, musieliśmy się zadowolić byle jaką oberżą i kiepskim obiadem” (Czartoryska 2018: 65) czy wreszcie charakterystyka z pierwszych dekad XX wieku: „Jeszcze na początku naszego [XX - K.B.] wieku Wrocław miał tu i ówdzie rustykalne rysy" (Scheyer 2018: 130). Nazewnicza spójność sprawia, że te pochodzące z różnych epok i kultur głosy opowiadają tę samą - wrocławską - opowieść. W takim ujęciu - kreślone już po polsku, w powojennej rzeczywistości - zdanie: „Życiem swoim jestem obecnie związana z Wrocławiem i tak już pozostanie" (Hoffman 2018: 251) staje się kontynuacją wcześniejszych barwnych wątków, a nie świadectwem wyjątkowo trudnego procesu stawania się mieszkańcem miasta bez tożsamości, miasta, „któremu amputowano pamięć” (Zawada 2015: 22).

Nie tylko Wrocław, lecz całe uniwersum opisywanego śląskiego świata wypełnione jest bez wyjątku polskimi nazwami. Polskie są nazwy rzek (Odra, Oława) i miast: „Bolesławiec, Chojnów, Legnica, Środa Śląska: schludne, przyjazne miejscowości [...]. Z Leśnicy do Wrocławia prowadzi długa aleja” (Herloßsohn 2018: 90) ${ }^{7}$.

5 Tytułowa łacińska nazwa miasta prawdopodobnie ma być wspólnym mianownikiem opowieści o różnych obliczach tego miejsca. Tak postrzegają tę nazwę Davies i Moorhouse: „Kiedy mamy dylemat, posługujemy się wprowadzoną ponad tysiąc lat temu przez duchownych mówiących i piszących po łacinie nazwą, która jest używana do dzisiaj - VRATISLAVIA" (Davies, Moorhouse 2011: 29). Nie bez znaczenia jest też, że nazwa Wratislavia od lat funkcjonuje w przestrzeni publicznej miasta, dzięki czemu nabiera semantycznej swojskości; przykładowo od 1966 organizowany jest prestiżowy Międzynarodowy Festiwal Oratoryjno-Kantatowy Wratislavia Cantans, a od 1996 roku funkcjonuje Orkiestra Kameralna Wratislavia.

${ }^{6} \mathrm{~W}$ jednostkowych przypadkach tytuły publikowanych tekstów sygnalizują istnienie wcześniejszych nazw miasta; na przykład: „Bressla” (Schedel 2018: 8) lub „Breslau, Vratislavia, Wratislawia” (Zeiller 2018: 18). Jednak nie są one w żaden sposób wyjaśniane ani też nie ma do nich nawiązań w głównej części tekstu - tam jest już mowa o Wrocławiu.

7 W tekstach pojawiają się także nieścisłości w przytaczaniu nazw własnych dzielnic miasta. Spójrzmy na przykład na opis dzielnic miejskich z pierwszych dekad XX wieku autorstwa Ersta Scheyera: „Na zachodzie leżały Grabiszynek (Greibschen, jak go nazywał Goethe), Siebenhufen [dawna dzielnica Siedem Łanów] i Gabitz [obecne Gajowice], Nowa Wieś, Marianhöfchen [obecnie Nowy Dwór]” (Scheyer 
Książka Orbis Wratislaviae nie jest kreacją pocztówkowo-idealnego wizerunku miasta. Redaktorzy nie boją się podejmować tematów trudnych, szczególnie z perspektywy polskiej, takich jak faszyzm; żal i poczucie straty Niemców, gdy po wojnie odwiedzają polski Wrocław - cień jedynie zamożnego Breslau; marazm i zagubienie pierwszego polskiego pokolenia wrocławian; brzydota socjalistycznego miasta. Te niepiękne obrazy miasta ożywiają budowany w książce wizerunek, dodają mu realności. „Wrocławski świat”, do którego zapraszają nas redaktorzy tomu, jest jednak przede wszystkim... wrocławski. Być może intencją autorów było właśnie oswojenie tej nadal trudnej przeszłości, uczynienie jej wspólną za pomocą współczesnej, przyjaznej (bo polskiej) nazwy miasta. Przenikające przytaczane opowieści słowa „Wrocław”, „Wrocławski” oraz inne polskie nazwy miejscowości dają jednak subtelny, kojący, ale i złudny obraz miasta o ciągłości historycznej, politycznej i społecznej.

Ten wątek długiego trwania jest także w dyskursie aktualnych władz miejskich. W czasie gdy piszę te słowa (maj 2020), Wrocław obchodzi 75. rocznicę swego powstania $^{8}$. Z tej okazji na stronie urzędu miejskiego (www.wroclaw.pl) widnieje hasło: „75 lat powojennego Wrocławia”. W sloganie tym kryje się presupozycja, że wcześniej — przed wojną - także był tu Wrocław, że powojenne miasto to kontynuacja, a nie nowa opowieść. Zupełnie inny wydźwięk miałoby hasło: „75 lat Wrocławia” — w takim wypadku Wrocław przestałby być spadkobiercą tworzonej wiele setek lat bogatej tradycji miejskiej, a stałby się zaledwie miejskim, kulturowo osieroconym oseskiem.

\section{Festung Breslau — jedyne (nazwane) dziedzictwo Breslau}

Siedemdziesiąta piąta rocznica powstania („powojennego”) Wrocławia jest też dobrym punktem wyjścia do opowiedzenia o jedynym okresie egzystencji niemieckiego miasta, który istnieje w dyskursie naukowym pod własną nazwą - Festung Breslau (także: Twierdza Breslau) ${ }^{9}$.

Festung Breslau zajmuje szczególne miejsce w obu analizowanych przeze mnie dziełach. O tym, jak bardzo ten moment w historii miasta jest istotny dla autorów Mikrokosmosu, świadczy prolog książki (zatytułowany znamiennie Götterdämmerung, czyli „zmierzch bogów”), poświęcony właśnie ostatniemu, dramatycznemu okresowi w historii Breslau. W tomie Orbis Wratislaviae nazwa Breslau pojawia się

2018: 131). Z treści wynika, że niemiecki autor tekstu użył w opisie polskiej nazwy Grabiszynek, niezrozumiałe i wymagające wyjaśnienia w przypisie jest odniesienie do Goethego i określenia Greibschen, $\mathrm{z}$ kolei inna nazwa dzielnicy (Nowa Wieś) przedstawiona została tylko w wersji polskiej.

${ }^{8}$ Niemieccy obrońcy miasta 6 maja 1945 roku podpisali kapitulację Breslau i tego też dnia Wrocław świętuje swoje urodziny.

${ }^{9}$ Festung Breslau (Twierdza Breslau) — od sierpnia 1944 do maja 1945 roku miasto zostało zamienione w wojskową twierdzę. Działania wojenne doprowadziły wtedy do jego zniszczenia niemal w $70 \%$. 
tylko w tym kontekście i to w dwóch rodzajach sytuacji. Po pierwsze, są to relacje z frontu: opisy walk, zniszczeń i mocnego przygnębienia mieszkańców Festung Breslau - na przykład wspomnienia Waltera Laßmanna Wielkanoc w Festung Breslau (2018). Po drugie są to opisy przejmowania dymiących zgliszczy twierdzy przez polskich osiedleńców. W tym wypadku zniszczone Breslau tworzy narracyjne tło rodzącego się Wrocławia: „W maju 1945 roku Breslau stał się Wrocławiem” (Laqueur 2018: 241). Użycie nazwy Breslau służy także podkreśleniu fizycznej, a w konsekwencji tożsamościowej, przemiany miasta:

Breslau, a raczej ta jego część, której nie można ani deportować, ani przemilczeć, której nie da się
przemalować czy też skuć, rzeka z jej dopływami i mostami, ulice, place, domy i ruiny - ten Breslau
nosi dzisiaj urzędową nazwę Wrocław. Ma to być fundament pod nową polską metropolię na Odrą,
miasto, które z Breslau niewiele będzie miało wspólnego - poza fizycznym położeniem - i będzie
przypominać raczej Warszawę czy Lublin niż Frankfurt lub Magdeburg. (Rhode 2018: 211)

$\mathrm{Na}$ tę istotność narracyjnego splecenia ostatnich dni Breslau z pierwszymi dniami Wrocławia zwróciła uwagę Maria Lewicka, która na początku XXI wieku przeprowadziła badania ilościowe nad świadomością historyczną wrocławian. Podsumowując wyniki dotyczące wiedzy o ważnych wydarzeniach z historii miasta, badaczka odnotowała, że współcześni wrocławianie wplatają wątek Festung Breslau do opowieści o początku Wrocławia:

Zdecydowanie na pierwszym miejscu jest przyłączenie Wrocławia do Polski — ów wielki big bang w pamięci współczesnych mieszkańców miasta. [...] We Wrocławiu historia zaczyna się [...] od początków miasta (konkretnie od założenia biskupstwa w roku 1000), potem jednak [...] następuje wielka dziura historyczna, po której pojawia się twierdza Breslau. Jest to, prawdę mówiąc, tylko preludium do właściwego polskiego okresu w historii miasta. (Lewicka 2006: 126-129)

Nazwa Festung Breslau nadal jest obecna we współczesnym dyskursie o Wrocławiu, została włączona do odświeżonej na początku XXI wieku pionierskiej opowieści fundacyjnej - narracji o pionierach, pierwszych polskich osiedleńcach, którzy $\mathrm{z}$ poświęceniem i oddaniem, $\mathrm{w}$ bardzo trudnych powojennych warunkach, wznosili Wrocław (zob. Biskupska 2020; Thum 2005; Zawada 2015) ${ }^{10}$. Być może Festung Breslau jest tożsamościowo ważne nie tylko ze względu na odniesienie do czasu pionierów, lecz także - jak podkreśla Wojciech Browarny — ze względu na symboliczne podobieństwo do najważniejszego polskiego „miasta ruin” - Warszawy. Nawiązanie we wrocławskiej opowieści do zrujnowanej, płonącej stolicy mogło legitymizować polskość Wrocławia, czynić podobnym te - polskie - miasta: „Topos warszawski w narracjach wrocławskiej tożsamości oznacza zatem pracę nad symbolami i obrazami, które wiarygodnie, komunikatywnie i cenzuralnie mogłyby

10 Ten wątek połączenia losów Festung Breslau i Wrocławia przewija się także we współczesnym dyskursie medialnym. Przykładowo na wspomnianej stronie urzędu miejskiego 5 maja 2020 roku, w przeddzień urodzinowego święta Wrocławia, został opublikowany artykuł o znamiennym tytule: Koniec Festung Breslau. Początek polskiego Wrocławia, w którym autorka najpierw przedstawia trudy życia pierwszych mieszkańców Wrocławia, a później relacjonuje zmagania wojenne ostatnich dni twierdzy (Wieliczko 2020). 
identyfikować miasto z polskością" (Browarny 2019: 37) ${ }^{11}$. Paradoksalnie, trwanie obrazów Festung Breslau w narracji o Wrocławiu jest dowodem trudności z przyjęciem spadku po Breslau — jedynym powszechnie nazywanym dziedzictwem kulturowym niemieckiego miasta jest moment jego straszliwej klęski, jego śmierci.

\section{Zakończenie}

Opowieść o dziedzictwie miasta jest inaczej prowadzona w obu analizowanych publikacjach. W opowieści o dziejach Wrocławia w ujęciu Normana Daviesa i Rogera Moorhouse’a słowem-kluczem jest „zmiana” — zmieniające się miejskie nazwy symbolizują nieustającą przemianę zarówno miasta, jak i jego mieszkańców. W ujęciu zaś Krzysztofa Ruchniewicza i Marka Zybury słowem-kluczem jest „kontynuacja" - trwanie i podtrzymywanie tradycji jednego miasta (Wrocławia) przez wieki. Drugie z tych ujęć dominuje we współczesnych opracowaniach historycznych ${ }^{12}$. Jest ono również łatwiejsze do przyjęcia przez współczesnych wrocławian, dla których spadek po Breslau jest nadal nieoczywistym zagadnieniem, a „proces przejmowania miasta [...] trwa już przez trzy pokolenia i jeszcze się nie zakończył” (Dzikowska 2006: 167). Dlatego też Wrocław nadal potrzebuje opowieści fundacyjnych wypełniających narracyjną pustkę po (nienazwanym) Breslau. Oprócz wspomnianej, przeżywającej rozkwit opowieści pionierskiej, w ostatnich latach w dyskursie publicznym pojawiła się kolejna istotna tożsamościowo narracja - o powodzi w 1997 roku, kiedy to wrocławianie poczuli się odpowiedzialni za swoje odziedziczone miasto i w jego obronie stanęli do walki z żywiołem (zob. Biskupska 2017).

Znawca problematyki dziedzictwa kulturowego Jacek Purchla podkreśla, że aby wpleść przeszłość miasta, nawet tę obcą i niezrozumiałą, do repertuaru dziedzictwa kulturowego, trzeba ją najpierw „umoić” - uczynić swoją. „Umojenie” nie oznacza jednak upodobnienia do tego, co własne - swojskie i akceptowane $-\mathrm{w}$,umojeniu” "chodzi o to, aby objąć, a nie wykluczać” (Purchla, Galusek 2017: 18). Objąć, czyli przyjąć takim, jakie coś jest — także nazwać po imieniu. Łatwiej byłoby o b j ąć spadek po Breslau, gdyby możliwe było wyjście poza mocno porządkującą wrocławską przeszłość (więc i dziedzictwo) kategorię narodowości. Innymi słowy, gdyby

11 Wojciech Browarny zaznacza także, że jeszcze długo po wojnie odwołanie do Festung Breslau było pozytywnym (sic!) skryptem narracyjnym, po który wrocławianie sięgali w sytuacjach trudnych czy groźnych — ostatnio w czasie powodzi w 1997 roku, a wcześniej w czasie stanu wojennego: „o strajkującym Wrocławiu, a zwłaszcza o strajkach okupacyjnych w wielkich zakładach przemysłowych mówi się w mieście »Festung Breslau«" (Browarny 2019: 94).

12 Oto przykłady niedawno opublikowanych pozycji historycznych dotyczących dziejów miasta przed 1945 rokiem i z Wrocławiem w tytule: J. Hytrek-Hryciuk (2019): Między prywatnym a publicznym. Życie codzienne we Wrocławiu w latach 1938-1944; M. Palica (2016): Wrocław 1916. Kronika miasta $w$ czasie wielkiej wojny; M. Zwierz (2016): Tradycje wystawiennicze we Wrocławiu w latach 1818-1948; I. Bińkowska (2013): Natura i miasto. Publiczna zieleń miejska we Wrocławiu od schyłku XVIII do początku XX wieku. 
„powrót do niepolskiej tradycji miasta stracił, tak częsty jeszcze, wymiar polsko-niemieckiej konkurencji o pamięć” (Traba 2006: 55). Także Purchla postuluje spojrzenie na dziedzictwo kulturowe w perspektywie szerszej niż narodowa:

Rozstrzygnięcie, co jest kłopotem, a co nie, jest w nas. To kwestia semantyki, naszego światopoglądu. Pytanie brzmi: czy chcemy na świat patrzeć w sposób zamknięty, zakodowany wedle jednego tylko klucza, dajmy na to narodowego, czy potrafimy spojrzeć szerzej, dostrzec więcej? (Purchla, Galusek 2017: 16-18)

\section{Bibliografia}

Ashworth G.J. (2007): Sfragmentaryzowane dziedzictwo: sfragmentaryzowany instrument sfragmentaryzowanej polityki, [w:] Dziedzictwo kulturowe w XXI wieku. Szanse i wyzwania, red. M.A. Murzyn, J. Purchla, Kraków, s. 29-42.

Bińkowska I. (2013): Natura i miasto. Publiczna zieleń miejska we Wrocławiu od schyłku XVIII do początku XX wieku, Wrocław.

Biskupska K. (2017): Pamiętam, że... O społecznej konstrukcji pamięci mieszkańców miast Ziem Zachodnich i Północnych, na przykładzie Wrocławia, „Opuscula Sociologica”, nr 1, s. 71-83.

Biskupska K. (2018): Miejsca pamięci a pamięć miejsca na przykładzie Wrocławia, [w:] Nowe i stare tendencje w obszarze pamięci społecznej, red. A. Szpociński, Z. Bogumił, Warszawa, s. 295-316.

Biskupska K. (2020): A beautiful flourish. The foundation story of Wroclaw (and Wroclaw residents), „Tekst i Dyskurs/Text und diskurs”, nr 13, s. 43-62.

Browarny W. (2019): Historie odzyskane. Literackie dziedzictwo Wrocławia i Dolnego Ślaska, Wrocław.

Coffin C. (2003): Reconstruals of the past - settlement or invasion?, [w:] Re/reading the past. Critical and functional perspectives on time and value, red. J.R. Martin, R. Wodak, Amsterdam-Philadelfia, s. $219-246$.

Czartoryska I. (2018): Z dziennika podróży do Cieplic, przeł. J. Bujańska, [w:] Orbis Wratislaviae. Wrocław w relacjach dawnych i współczesnych, red. K. Ruchniewicz, M. Zybura, Wrocław, s. 65-68.

Davies N. (2011a): Przedmowa, [w:] N. Davies, R. Moorhouse, Mikrokosmos. Portret miasta środkowoeuropejskiego. Vratislavia, Breslau, Wrocław, przeł. A. Pawelec, Kraków, s. 11-16.

Davies N. (2011b): Przedmowa do polskiego wydania, [w:] N. Davies, R. Moorhouse, Mikrokosmos. Portret miasta środkowoeuropejskiego. Vratislavia, Breslau, Wrocław, przeł. A. Pawelec, Kraków, s. $9-10$.

Davies N., Moorhouse R. (2011): Mikrokosmos. Portret miasta środkowoeuropejskiego. Vratislavia, Breslau, Wrocław, przeł. A. Pawelec, Kraków.

Dutkiewicz R. (2018): Wrocław - miasto otwarte, [w:] Orbis Wratislaviae. Wrocław w relacjach dawnych $i$ współczesnych, red. K. Ruchniewicz, M. Zybura, Wrocław, s. 6.

Dzikowska E. (2006): Tożsamość Wrocławia(n), czyli o możliwościach życia ponad podziałami, [w:] My Wrocławianie. Społeczna przestrzeń miasta, red. P. Żuk, J. Pluta, Wrocław, s. 165-180.

Galusek Ł., Jagodzińska K. (2014): Dziedzictwo, [w:] Modi memorandi. Leksykon kultury i pamięci, red. M. Saryusz-Wolska, R. Traba, Warszawa, s. 106-111.

Gilbert G.N., Mulkay M.J. (1984): Opening Pandora's Box: A Sociological Analysis of Scientists' Discourse, Cambridge.

Herloßsohn K. (2018): Imponującej sylwetki to miasto nie ma, przeł. A. Wziątek, [w:] Orbis Wratislaviae. Wrocław w relacjach dawnych i współczesnych, red. K. Ruchniewicz, M. Zybura, Wrocław, s. 90-96.

Hoffman J. (2018): Wrocław ma już na pewno wrocławian, [w:] Orbis Wratislaviae. Wrocław w relacjach dawnych $i$ wspótczesnych, red. K. Ruchniewicz, M. Zybura, Wrocław, s. 251-255. 
Hytrek-Hryciuk J. (2019): Między prywatnym a publicznym. Życie codzienne we Wrocławiu w latach 1938-1944, Wrocław.

Jedlicki J. (1993): Źle urodzeni, czyli o doświadczeniu historycznym, Londyn-Warszawa.

Laqueur W. (2018): Powrót. List $z$ Wrocławia, [w:] Orbis Wratislaviae. Wrocław w relacjach dawnych i współczesnych, red. K. Ruchniewicz, M. Zybura, Wrocław, s. 238-247.

Laßmann W. (2018): Wielkanoc w Festung Breslau, przeł. A. Wziątek, [w:] Orbis Wratislaviae. Wrocław w relacjach dawnych i współczesnych, red. K. Ruchniewicz, M. Zybura, Wrocław, s. 169-175.

Lewicka M. (2006): Dwa miasta - dwa mikrokosmosy. Wrocław i Lwów w pamięci swój mieszkańców, [w:] My Wrocławianie. Społeczna przestrzeń miasta, red. P. Żuk, J. Pluta, Wrocław, s. 99-134.

Margiela-Korczewska D. (2011): „Poświęcić czas historii” - w poszukiwaniu wrocławskiego dziedzictwa. O polityce historycznej lat dziewięćdziesiątych we Wrocławiu, [w:] Błogosławiony kraj? Szkice o historii i pamięci Dolnego Ślaska, red. D. Margiela-Korczewska, K. Ruchniewicz, Wrocław, s. 173-196.

Palica M. (2016): Wrocław 1916. Kronika miasta w czasie wielkiej wojny, Wrocław.

Potter J., Wetherell M. (1994): Some Practical Issues in Analysing Discourse, [w:] Analyzing Qualitative Data, red. A. Bryman, R.G. Burgess, London, s. 47-66.

Purchla J., Galusek Ł. (2017): Kwestia dojrzałości. Z profesorem Jackiem Purchla rozmawia Łukasz Galusek, „Herito. Dziedzictwo, kultura, współczesność”, nr 29, s. 12-25.

Rhode G. (2018): Wrocław 1949, [w:] Orbis Wratislaviae. Wrocław w relacjach dawnych i współczesnych, red. K. Ruchniewicz, M. Zybura, Wrocław, s. 211-215.

Ruchniewicz K., Zybura M. (red.) (2018): Orbis Wratislaviae. Wrocław w relacjach dawnych i wspótczesnych, Wrocław.

Thum G. (2005): Obce miasto. Wrocław 1945 i potem, Wrocław.

Traba R. (2006): Historia - przestrzeń dialogu, Warszawa.

Tuszyńska A. (2003): Kiedy myślę Polska, myślę „Europa”. Rozmowa z Ewą Stachniak, „Odra” 6, s. 20-22.

Wassermann Ch. (2018): To nie jest już niemiecki Breslau, [w:] Orbis Wratislaviae. Wrocław w relacjach dawnych i współczesnych, red. K. Ruchniewicz, M. Zybura, Wrocław, s. 228-231.

Wieliczko M. (2020): Koniec Festung Breslau. Początek polskiego Wrocławia, https://www.wroclaw.pl/ extra/koniec-festung-breslau-poczatek-polskiego-wroclawia (dostęp: 15.05.2020).

Wooffitt R. (2005): Conversational Analysis and Discourse Analysis, London.

Schedel H. (2018): Bressla, przeł. A. Wziątek, [w:] Orbis Wratislaviae. Wrocław w relacjach dawnych i współczesnych, red. K. Ruchniewicz, M. Zybura, Wrocław, s. 8-9.

Scheyer E. (2018): Ze wspomnień, przeł. A. Wziątek, [w:] Orbis Wratislaviae. Wrocław w relacjach dawnych i wspótczesnych, red. K. Ruchniewicz, M. Zybura, Wrocław, s. 130-137.

Schlögel K. (2009): W przestrzeni czas czytamy. O historii cywilizacji i geopolityce, przeł. I. Drozdowska, Ł. Musiał, Poznań.

Zawada A. (2015): Drugi Bresław, Wrocław.

Zeiller M. (2018): Breslau, Vratislavia, Wratislavia, przeł. A. Wziątek, [w:] Orbis Wratislaviae. Wrocław $w$ relacjach dawnych $i$ współczesnych, red. K. Ruchniewicz, M. Zybura, Wrocław, Wrocław, s. $18-24$.

Zwierz M. (2016): Tradycje wystawiennicze we Wrocławiu w latach 1818-1948, Wrocław.

Żyłko B. (2000): Wstęp tłumacza. Miasto jako przedmiot badań semiotyki kultury, [w:] W. Toporow, Miasto i mit, Gdańsk, s. 5-30. 


\section{Breslau. The name of the city as a cultural heritage. An outline of the issues from historic discourse analysis perspective}

Summary

In the article I trace the tactics of recalling (and avoiding) earlier names of the contemporary Wrockaw as an element of creating its cultural heritage. On the example of historical studies and using the method of discourse analysis, I present the mechanisms of creating differently accented pasts of the city. Based on the use of a historical name (e.g. Breslau) or consistently only contemporary one (Wrocław) I indicate that the strategy for choosing the name is based on different, ideologically conditioned narratives. Some researchers, using earlier historical names of the city, create an image of a constantly changing European urban center, while others, using only the present name, construct the image of the city as a continuator of a centuries-old urban tradition, with the dominant Polish perspective on historical narrative.

Keywords: cultural heritage, Wrocław, Breslau, discourse analysis, social memory. 